\title{
REKOMENDASI PENENTUAN TITIK TEMPAT PENAMPUNGAN SAMPAH SEMENTARA DI KECAMATAN KEDUNGKANDANG KOTA MALANG
}

\author{
Eka Zuli Pratiwi, Christia Meidiana, Wawargita Permata Wijayanti \\ JurusanPerencanaan Wilayah dan Kota Fakultas Teknik Universitas Brawijaya \\ Jalan Mayjen Haryono 167 Malang 65145 -Telp (0341)567886 \\ ekazulipratiwi@gmail.com
}

\begin{abstract}
ABSTRAK
Pengelolaan sampah merupakan salah satu fokus Pemerintah Kota Malang dalam mendukung program 100-0100 milik Kementerian Pekerjaan Umum dan Perumahan Rakyat tahun 2015-2019. Penduduk Kecamatan Kedungkandang hingga saat ini belum seluruhnya terlayani oleh pengelolaan sampah. Penduduk yang tidak terlayani oleh pengelolaan sampah sebesar $37 \%$ atau $152,2 \mathrm{~m}^{3} /$ hari dari total volume sampah yang ada di Kecamatan kedungkandang sebesar $412,3 \mathrm{~m}^{3} / \mathrm{hari}$. Kondisi tersebut tidak sesuai dengan target pelayanan persampahan pemerintah Kota Malang sebesar 100\%. Target tersebut mendukung Kementrian Pekerjaan Umum dan Perumahan Rakyat yang memuat program 100-0-100 artinya 100\% akses air minum aman, 0\% permukiman kumuh dan $100 \%$ sanitasi layak pada tahun 2015 - 2019. Penelitian ini membahas tentang peningkatan daerah pelayanan persampahan di Kecamatan kedungkandang dengan cara menambah titik TPS baru dan kapasitas TPS. Analisis yang digunakan dalam penelitian ini yaitu analisis kesesuaian TPS dan alat pengumpul sampah, analisis overlay, network analysis, analisis operasional pengangkutan. Dalam meningkatkan daerah pelayanan persampahan di Kecamatan Kedungkandang perlu kriteria untuk menentukan rekomendasi yang akan dilakukan. Kriteria yang digunakan berdasarkan Perda Kota Malang no 10 tahun 2010, PERMEN PU No 3 Tahun 2013 tentang sarana dan prasarana pengelolaan sampah, SNI-3242-2008 tentang tata cara pengelolaan persampahan permukiman, Rencana Induk Persampahan Kota Malang Tahun 2016. Hasil penelitian tersebut menunjukkan bahwa TPS yang perlu penambahan kapasitas TPS yaitu TPS Cemorokandang, TPS Kedungkandang, TPS Lesanpuro, TPS Buring, TPS Arjowinangun, TPS Danau Bratan. Sedangkan penambahan TPS baru berada pada Kelurahan Bumiayu, Kelurahan Tlogowaru, Kelurahan Kedungkandang, Kelurahan Cemorokandang,Kelurahan Wonokoyo.
\end{abstract}

Kata Kunci :daerah pelayanan, TPS, pengangkutan sampah

\section{ABSTRACT}

A waste management that supports 100-0-100 program of Ministry of Public Works and Housing (2015-2019) is one of main concerns of Malang city government. The community of Kedungkandang District has not been served fully by the waste management service. Only 37\% of the Kedungkandang District Community which is served by waste management service or only 152,2 $\mathrm{m}^{3}$ / day from the total volume of waste production which is $412,3 \mathrm{~m}^{3} /$ day. This is not appropriate with the target of waste service in Malang City (100\%). This target aimed to support the program of Public Work and Housing Ministry which is 100-0-100 that means 100\% access to safe drinking water, $0 \%$ slum settlement and 100\% access to sanitation service in 2015-2019. This research discusses the improvement the waste service area in Kedungkandang district by adding new transfer points and increasing the capacity of transfer points. The analyzes used in this study are the analysis of transfer point and waste collection tools conformity, overlay analysis, network analysis, operational waste transport analysis. The criteria needed to increase the waste service area in Kedungkandang District, and to determine the recommendation that will be applied. The criteria used is based on the regulation of Malang City no (10) 2010, PERMEN PU No (3) 2013 about the waste management infrastructure and Masterplan of Waste Management 2016, SNI 3242-2008 about the procedure of waste management in the settlement. The result of this research shows that the transfer points' capacity which need to be expanded such as Cemorokandang transfer point, Kedungkandang transfer point, Lesanpuro transfer point, Arjowinangun transfer point, Danau Bratan transfer point, while the establishment of the new transfer points will be in Bumiayu Village, Tlogowaru Village, Kedungkandang Village, Cemorokandang Village, Wonokoyo Village.

Keywords: Service area, transfer points, waste transport.

\section{PENDAHULUAN}

Permasalahan sampah merupakan permasalahan lingkungan yang selalu menjadi isu di hampir seluruh wilayah perkotaan di Indonesia. Permasalahan sampah akan terus meningkat beriringan dengan tingkat pertumbuhan penduduk yang pertumbuhannya tidak terkendali. Tidak bisa dipungkiri sampai saat ini masih banyak masyarakat yang berperilaku buruk terhadap lingkungan, misalnya 
membuang sampah sembarangan. Permasalahan sampah tersebut banyak dijumpai di Indonesia yang jika tidak diperhatikan dengan baik maka akan mengakibatkan masalah kesehatan, kenyamanan, keindahan, dan lain sebagainya (Pramono, 2013). Kota Malang merupakan salah satu kota besar yang ada di Indonesia dengan jumlah penduduk tahun 2016 sebanyak 887.443 jiwa (BPS, 2017). Volume sampah yang dihasilkan penduduk Kota Malang sebesar 2.481 $\mathrm{m}^{3} /$ hari. Sampah yang terkelola sebanyak 1.370 $\mathrm{m}^{3} /$ hari dan yang belum terkelola sebanyak $1.111 \mathrm{~m}^{3} /$ hari (Dinas Kebersihan dan Pertamanan Kota Malang, 2013). Daerah di Kota Malang khususnya Kecamatan Kedungkandang memiliki daerah yang belum terakses oleh pelayanan pengelolaan sampah (Buku Putih Sanitasi Kota Malang tahun 2014). Berdasarkan data Rencana Induk Persampahan 2016 dari Dinas Lingkungan Hidup, produksi sampah di Kecamatan Kedungkandang pada tahun 2016 yang dihasilkan oleh masyarakat sebesar $412,3 \mathrm{~m}^{3} /$ hari sedangkan produksi sampah yang dilayani oleh petugas sampah hanya sebesar $260,1 \mathrm{~m}^{3} /$ hari dan produksi sampah sebesar $152,2 \mathrm{~m}^{3} /$ hari tidak terangkut menuju TPA.

Berdasarkan hasil survei 2017 kondisi pengelolaan sampah yang ada di Kecamatan Kedungkandang masih belum maksimal karena penyediaan sarana dan prasarana seperti gerobak sampah, TPS, dan truk pengangkut sampah yang masih terbatas. Menurut Rizal, 2017 bahwa permasalahan yang ada di sistem pemindahan dapat berimbas ke sistem yang lainnya seperti sistem pengumpulan, sistem pengolahan dan sistem pengangkutan karena sistem tersebut saling berkaitan satu dengan yang lainnya. Akibat dari permasalahan di TPS Kecamatan Kedungkandang sistem pengumpulan, sistem pengolahan, sistem pengangkutan tidak berjalan dengan optimal.

Berdasarkan permasalahan tersebut terdapat indikasi bahwa pelayanan persampahan di Kecamatan Kedungkandang belum berjalan secara optimal untuk mengelola sampah. Oleh karena itu, perlu adanya penelitian yang membahas tentang peningkatan pelayanan persampahan di Kecamatan Kedungkandang.

\section{METODE PENELITIAN}

Kecamatan Kedungkandang merupakan salah satu kecamatan yang ada di Kota Malang. Luas wilayah Kecamatan Kedungkandang adalah
$3.989 \mathrm{Ha}$ atau 39,89 $\mathrm{Km}^{2}$ paling luas dibandingkan dengan kecamatan lain di Kota Malang. Kecamatan Kedungkandang memiliki 12 kelurahan yang tersebar disetiap kelurahan. Berikut adalah lokasi titik TPS yang ada di Kecamatan Kedungkandang yang dapat dilihat pada Gambar 1.

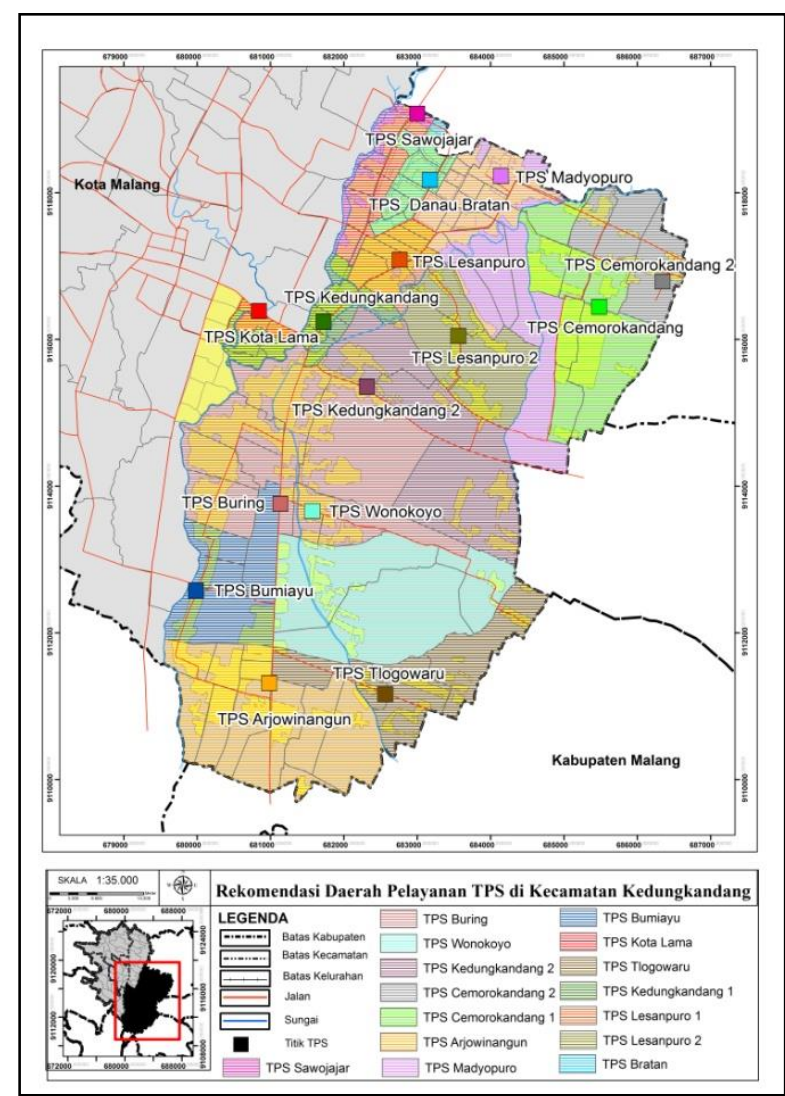

Gambar 1. Lokasi dan Daerah Pelayanan TPS Kecamatan kedungkandang

Metode yang digunakan untuk menentukan titik TPS Kecamatan Kedungkandang adalah dengan menggunakan perhitungan kebutuhan dan kapasitas TPS berdasarkan SNI 342 tahun 2008 serta mempertimbangkan kondisi fisik kawasan dengan menggunakan teknik overlay dengan software ArcGIS. Di samping itu, untuk menentukan bagaimana rute pengangkutan sampah digunakan teknik analisa spasial melalui network analysis. Alur analisa dalam penelitian ini dapat dilihat pada Gambar 2. 


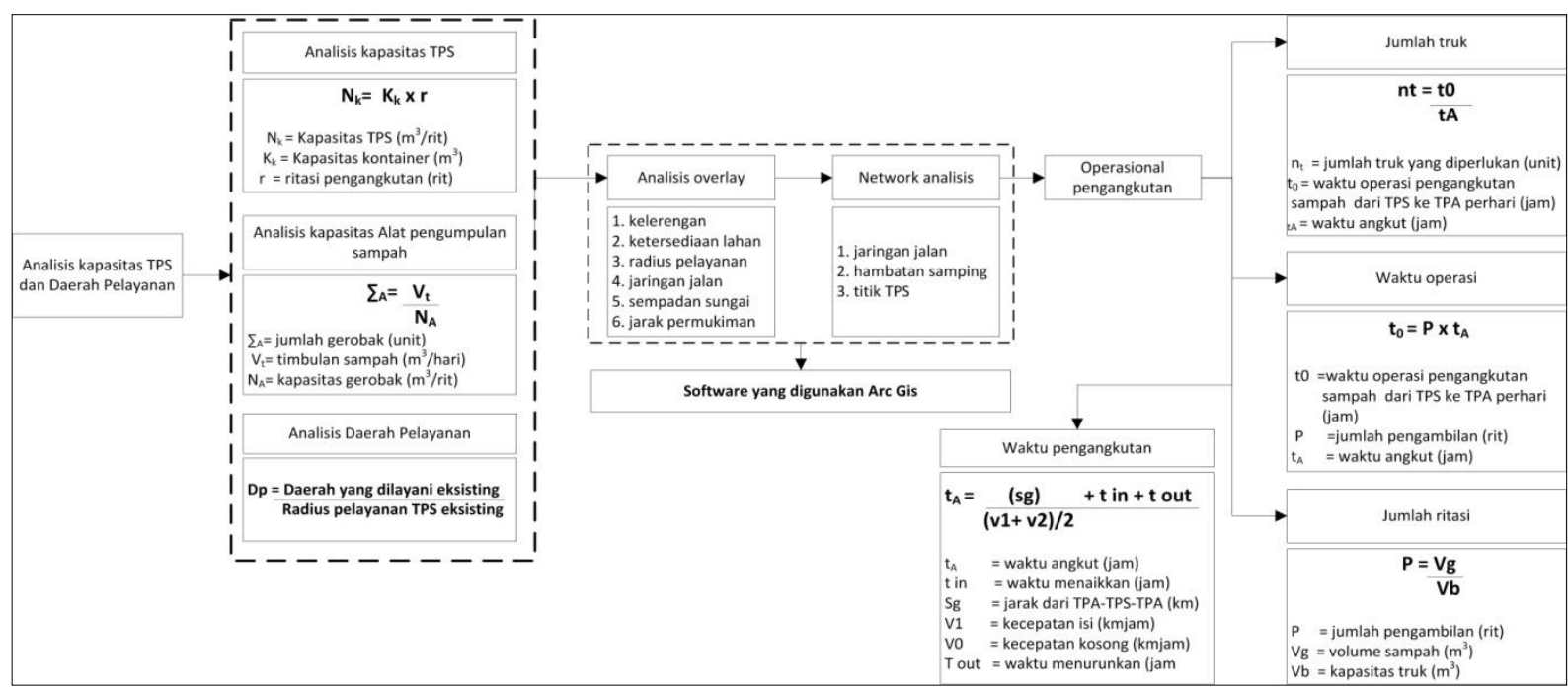

Gambar 2. Kerangka Analisa

\section{HASIL DAN PEMBAHASAN}

Kecamatan Kedungkandang merupakan salah satu kecamatan yang ada di Kota Malang. Luas wilayah Kecamatan Kedungkandang adalah 3.989 $\mathrm{Ha}$ atau 39,89 $\mathrm{Km}^{2}$ paling luas dibandingkan dengan kecamatan lain di Kota Malang. Kecamatan Kedungkandang memiliki 12 kelurahan diantaranya 9 kelurahan yang sudah memiliki tepat penampungan sampah sedangkan tiga kelurahan belum memiliki tempat penampungan sampah berada di Kelurahan Wonokoyo, Kelurahan Bumiayu, Kelurahan Tlogowaru. Masing-masing TPS yang ada di Kecamatan Kedungkandang memiliki karakteristik yang berbeda sesuai dengan tipe TPS yang disediakan.

\section{Analisis Kapasitas TPS dan Daerah Pelayanan}

Sarana pengumpulan dan sarana pemindahan sampah yang melayani Kecamatan Kedungkandang terdiri dari gerobak sampah dan TPS. Gerobak sampah dan TPS sampah dikelola oleh dinas kebersihan Kota Malang. Untuk Sarana pengumpulan dan sarana pemindahan sampah harus menyesuaikan sampah yang dihasilkan oleh masyarakat. Berikut adalah perhitungan kapasitas saranayang tersedia di TPS Kedungkandang yaitu

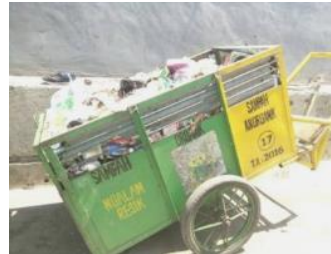

(a)

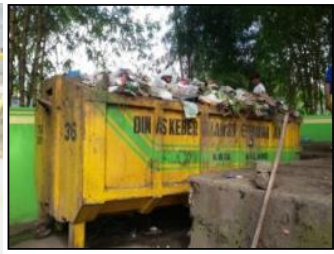

(b)
Gambar 3. sarana pengelolaan sampah. Keterangan:

(a) alat pengumpulan sampah (b) TPS a. Alat pengumpul sampah merupakan moda yang digunakan untuk mengambil sampah dari penduduk, yang berbentuk gerobak. Gerobak sampah memiliki ukuran panjang 1,2 meter, lebar 0,6 meter dan tinggi 0,8 meter dengan kapasitas sebesar $1 \mathrm{~m}^{3}$. Berikut adalah analisis kapasitas alat pengumpul sampah di Kecamatan Kedungkandang dapat dilihat pada Tabel 1 .

Tabel 1. Kesesuaian Kapasitas Alat Pengumpulan Sampah

\begin{tabular}{|c|c|c|c|c|}
\hline Nama TPS & $\begin{array}{c}\text { Timbu } \\
\text { nan } \\
\text { Sampa } \\
\text { h }\left(\mathbf{m}^{3} /\right. \\
\text { hari) }\end{array}$ & $\begin{array}{c}\text { Kapasita } \\
\text { s } \\
\text { gerobak } \\
\text { yang } \\
\text { disediak } \\
\text { an }\left(\mathbf{m}^{3}\right)\end{array}$ & $\begin{array}{c}\text { Kapasit } \\
\text { as } \\
\text { Geroba } \\
\text { k yang } \\
\text { Dibutu } \\
\text { hkan } \\
\left(\mathbf{m}^{\mathbf{3}}\right)\end{array}$ & $\begin{array}{l}\text { Keses } \\
\text { uaian }\end{array}$ \\
\hline TPS & & & & sesuai \\
\hline Kedungkandang & 14,83 & 20 & 15 & \\
\hline TPS Lesanpuro & 34,62 & 40 & 35 & sesuai \\
\hline TPS Buring & 37,03 & 40 & 38 & sesuai \\
\hline TPS Bratan & 22,90 & 30 & 23 & sesuai \\
\hline TPS Velodrome & 50,24 & 54 & 51 & sesuai \\
\hline TPS Sawojajar & 32,13 & 40 & 33 & sesuai \\
\hline $\begin{array}{l}\text { TPS } \\
\text { Arjowinangun }\end{array}$ & 16,92 & 20 & 17 & sesuai \\
\hline $\begin{array}{l}\text { TPS } \\
\text { Cemorokandang }\end{array}$ & 12,61 & 16 & 13 & sesuai \\
\hline TPS Kota Lama & 21,85 & 30 & 22 & sesuai \\
\hline
\end{tabular}

Berdasarkan Tabel 1 dapat diketahui bahwa alat pengumpul sampah yang ada di masing-masing TPS sudah sesuai dengan kebutuhan sampah yang ada sehingga sampah dari masyarakat dapat terangkut dengan maksimal. Hanya saja perlu perbaikan pada gerobak sampah yang sudah tidak layak digunakan seperti berkarat dan banyak lubang karena sudah lama pemakaiannya dan tidak ada yang merawat sehingga gerobak sangat mudah rusak. 
b. TPS merupakan sarana persampahan yang digunakan untuk menimbun sampah secara sementara sebelum dibawa ke TPA. TPS di Kecamatan Kedungkandang mayoritas berbentuk kontainer dengan kapasitas $8 \mathrm{~m}^{3}$.

Tabel 2. Kesesuaian Kapasitas TPS di Kecamatan Kedungkandang

\begin{tabular}{lccc}
\hline \multicolumn{1}{c}{ TPS } & $\begin{array}{c}\text { Produksi } \\
\text { sampah } \\
\left(\mathbf{m}^{\mathbf{3}} \mathbf{h a r i}\right)\end{array}$ & $\begin{array}{c}\text { Kapasita } \\
\mathbf{s} \text { TPS } \\
\left(\mathbf{m}^{\mathbf{3}}\right)\end{array}$ & $\begin{array}{c}\text { Kesesuaia } \\
\mathbf{n}\end{array}$ \\
\hline $\begin{array}{l}\text { TPS } \\
\text { Kedungkandang }\end{array}$ & 14,83 & 16 & Sesuai \\
\hline TPS Lesanpuro & 47,41 & 24 & $\begin{array}{c}\text { Tidak } \\
\text { sesuai }\end{array}$ \\
\hline TPS Buring & 86,41 & 32 & $\begin{array}{c}\text { Tidak } \\
\text { sesuai }\end{array}$ \\
\hline TPS Bratan & 22,90 & 16 & $\begin{array}{c}\text { Tidak } \\
\text { sesuai }\end{array}$ \\
\hline TPS Velodrome & 50,24 & 58 & Sesuai \\
\hline TPS Sawojajar & 31,13 & 32 & Sesuai \\
\hline $\begin{array}{l}\text { TPS } \\
\text { Arjowinangun }\end{array}$ & 16,92 & 16 & $\begin{array}{c}\text { Tidak } \\
\text { sesuai }\end{array}$ \\
\hline $\begin{array}{l}\text { TPS } \\
\text { Cemorokandang }\end{array}$ & 12,61 & 8 & $\begin{array}{c}\text { Tidak } \\
\text { sesuai }\end{array}$ \\
\hline TPS Kota Lama & 21,85 & 8 & $\begin{array}{c}\text { Tidak } \\
\text { sesuai }\end{array}$ \\
\hline
\end{tabular}

Berdasarkan tabel 2 menunjukkan bahwa terdapat TPS yang kapasitasnya tidak mampu untuk menampung seluruh sampah penduduk sehingga perlu adanya penambahan kapasitas pada tiap TPS tersebut. TPS yang kapasitasnya belum mampu mencukupi produksi sampah yang masuk ke TPS adalah TPS Lesanpuro, TPS Buring, TPS Bratan, TPS Arjowinangun, TPS Cemorokandang, TPS Kota Lama.

Selain itu, daerah pelayanan sampah TPS di Kecamatan Kedungkandang belum melayani seluruh penduduk. Berikut adalah daerah pelayanan TPS Kecamatan kedungkandang dapat dilihat pada Tabel 3.

Tabel 3. Daerah Pelayanan Sampah tiap TPS

\begin{tabular}{|c|c|c|}
\hline TPS & Daerah Pelayanan & $\begin{array}{c}\text { Prosen } \\
\text { tase }\end{array}$ \\
\hline TPS Kota Lama & RW 6, RW 7, RW 4 & $52 \%$ \\
\hline $\begin{array}{l}\text { TPS } \\
\text { Kedungkandang }\end{array}$ & RW 1, RW 2, RW 3, RW 6 & $57 \%$ \\
\hline TPS Buring & $\begin{array}{l}\text { Buring : RW 1, RW 2, } \\
\text { SMPN 10 Malang } \\
\text { Bumiayu : RW 1, RW 2, } \\
\text { RW 3 } \\
\text { Wonokoyo : RW 1, RW 2 }\end{array}$ & $43 \%$ \\
\hline $\begin{array}{l}\text { TPS } \\
\text { Arjowinangun }\end{array}$ & $\begin{array}{l}\text { Arjowinangun : RW 1, RW } \\
\text { 2, RW 5, RW 7, RW } 9 \\
\text { Tlogowaru : RW 1, RW } 2\end{array}$ & $39 \%$ \\
\hline TPS Lesanpuro & $\begin{array}{l}\text { RW 1, RW2, RW 3, RW 4, } \\
\text { RW 7, RW 8, RW 10, RW } \\
11\end{array}$ & $94 \%$ \\
\hline TPS Madyopuro & $\begin{array}{l}\text { RW 1, RW2, RW 3, RW 4, } \\
\text { RW 5, RW 6, RW 7, RW } \\
\text { 8, RW 9, RW 10, RW 11, } \\
\text { RW 12, RW 13, RW 14, } \\
\text { RW 15, Sampah } \\
\text { Pendidikan }\end{array}$ & $100 \%$ \\
\hline
\end{tabular}

\begin{tabular}{|c|c|c|}
\hline TPS & Daerah Pelayanan & $\begin{array}{c}\text { Prosen } \\
\text { tase }\end{array}$ \\
\hline TPS Sawojajar & $\begin{array}{l}\text { RW 1, RW 2, RW 3, RW } \\
4 \text {, RW 6, RW 9, RW 11, } \\
\text { RW } 14\end{array}$ & $100 \%$ \\
\hline TPS Danau Bratan & 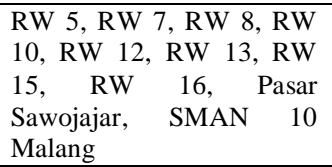 & $100 \%$ \\
\hline $\begin{array}{l}\text { TPS } \\
\text { Cemorokandang }\end{array}$ & $\begin{array}{l}\text { RW 1, RW 2, RW 5, RW } \\
\text { 7, RW 8, RW } 9\end{array}$ & $41 \%$ \\
\hline
\end{tabular}

Berikut adalah daerah yang tidak terlayani oleh pengelolaan sampah di Kecamatan kedungkandang dapat dilihat pada Tabel 4.

Tabel 4. Daerah yang Tidak Terlayani oleh Pengelolaan Sampah

\begin{tabular}{lc}
\hline \multicolumn{1}{c}{ TPS } & Daerah yang Tidak Terlayani \\
\hline TPS Kota Lama & RW 5, RW 7, RW 8, RW 9, RW \\
& 10, RW 11 \\
\hline TPS Kedungkandang & RW 4, RW 5, RW 7 \\
\hline TPS Buring & RW 3, RW 4, RW 5 \\
\hline TPS Arjowinangun & RW 3, RW4, Rw 5, RW 6 \\
\hline TPS Lesanpuro & RW 6, RW 5, RW 9 \\
\hline TPS Madyopuro & - \\
\hline TPS Sawojajar & - \\
\hline TPS Danau Bratan & - \\
\hline TPS & RW 3, RW 4, RW 10, RW 11 \\
\hline
\end{tabular}

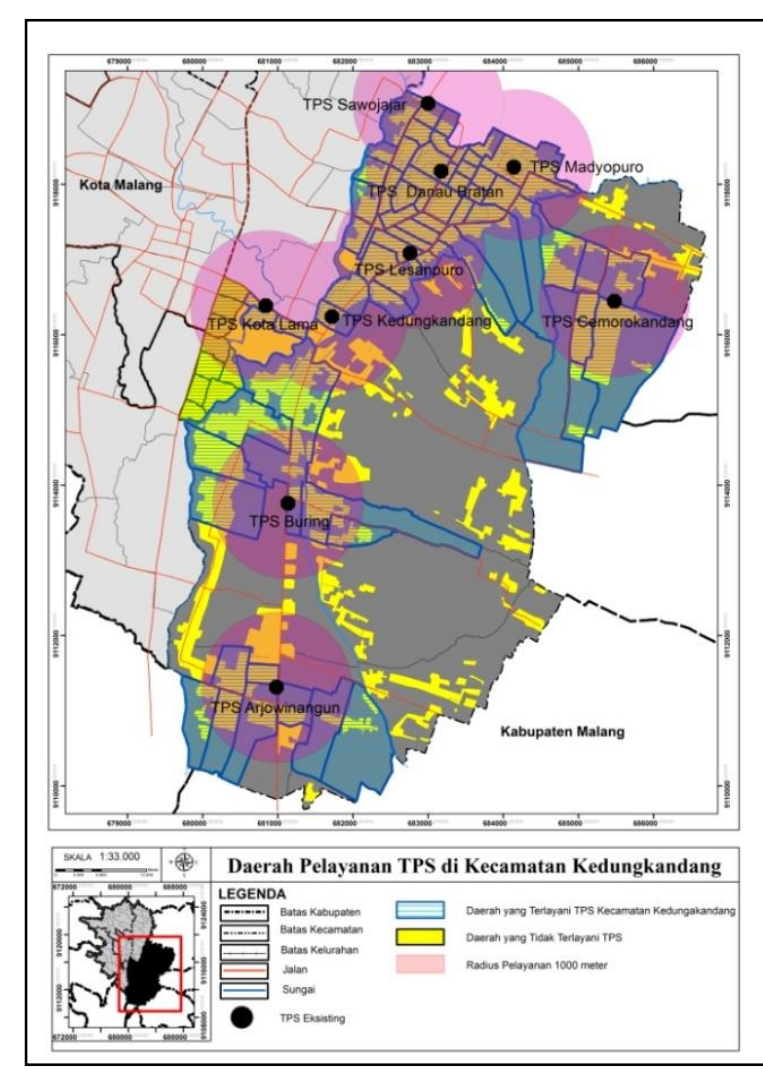

Gambar 4. Daerah Pelayanan TPS di Kecamatan Kedungkandang

Berdasarkan gambar 4 daerah yang tidak terlayani oleh pengelolaan sampah mayoritas memiliki jarak lebih dari $1000 \mathrm{~m}$ dari TPS yang tersedia padahal berdasarkan Perda Kota Malang 
no 10 tentang Pengelolaan Sampah menyebutkan bahwa jangkauan pelayanan TPS memiliki jarak paling jauh maksimal 1000 meter sehingga perlu penambahan TPS baru untuk mempermudah jangkauan masyarakat dalam membuang sampah ke TPS.
Rencana yang akan dilakukan bertujuan untuk meningkatkan pelayanan persampahan di Kecamatan Kedungkandang untuk dapat memenuhi target pelayanan sampah Kota Malang sebesar $100 \%$. Untuk menentukan rekomendasi pada tiap-tiap TPS harus memenuhi kriteriakriteria pada Tabel 5.

\section{Rencana TPS dan alat pengumpulan sampah}

Tabel 5. Kriteria rekomendasi peningkatan daerah pelayanan

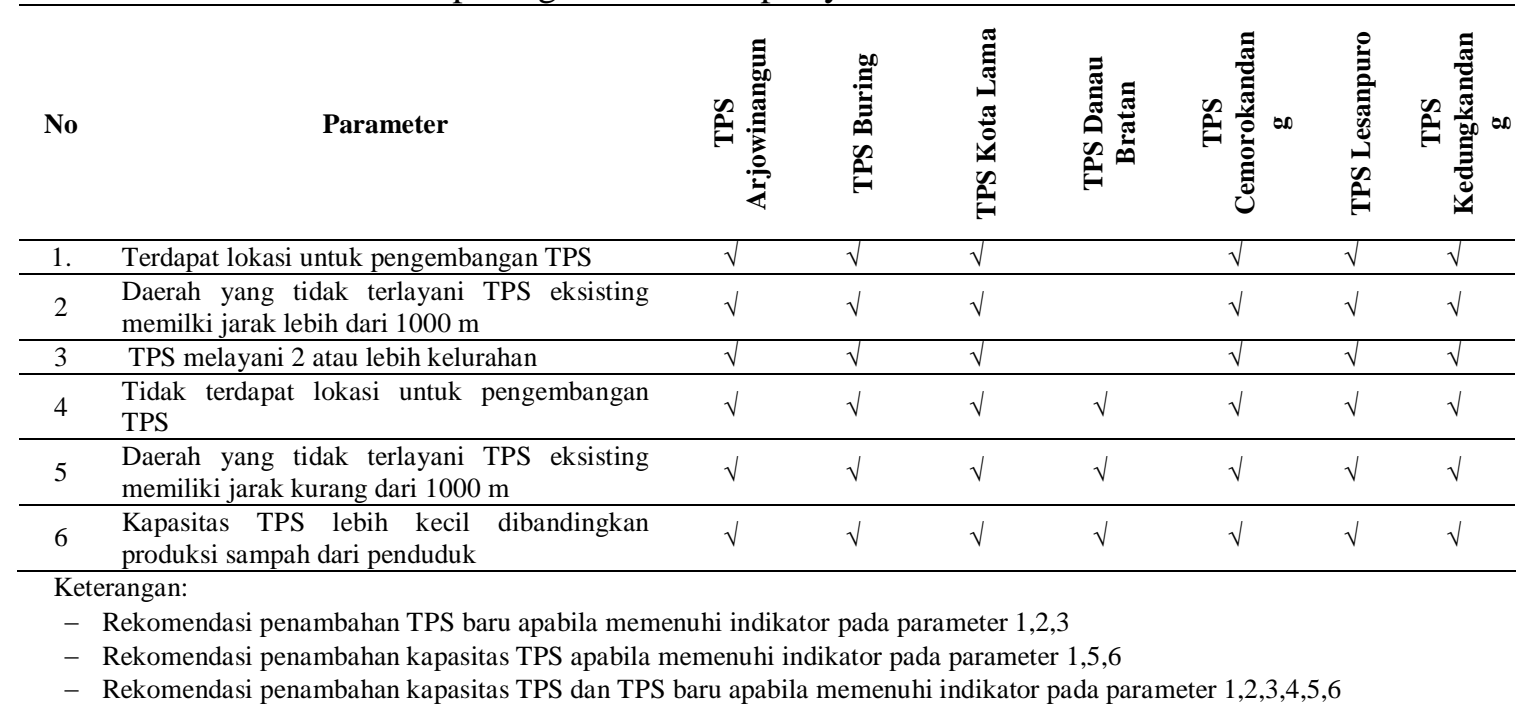

Berikut adalah rekomendasi pelayanan persampahan tiap-tiap TPS yang ada di Kecamatan Kedungkandang

1. TPS Kedungkandang

a. Penambahan kapasitas di TPS

Kedungkandang

Berikut adalah produksi sampah yang masuk kedalam penambahan kapasitas di TPS Kedungkandang

Tabel 6. Produksi sampah Baru yang Masuk ke TPS Kelurahan Kedungkandang

\begin{tabular}{llr}
\hline \multirow{2}{*}{ Kelurahan } & \multicolumn{1}{c}{$\begin{array}{c}\text { Daerah } \\
\text { Pelayanan }\end{array}$} & $\begin{array}{c}\text { Produksi Sampah } \\
\left(\mathbf{m}^{\mathbf{3}} \text { /hari) }\right.\end{array}$ \\
\hline \multirow{4}{*}{ Kota Lama } & RW 5 & 4,27 \\
\cline { 2 - 3 } & RW 8 & 9,33 \\
\cline { 2 - 3 } & RW 9 & 4,64 \\
\cline { 2 - 3 } & RW 10 & 10,74 \\
\cline { 2 - 3 } & RW 11 & 4,59 \\
\hline Kedungkandang & RW 7 & 1,71 \\
\hline Total sampah yang dihasilkan & $\mathbf{3 5 , 2 7}$ \\
\hline
\end{tabular}

Tabel 7. Timbunan Sampah yang Masuk ke TPS Kedungkandang

\begin{tabular}{llr}
\hline \multirow{2}{*}{ Kelurahan } & \multicolumn{1}{c}{$\begin{array}{c}\text { Daerah } \\
\text { Pelayanan }\end{array}$} & \multicolumn{1}{c}{$\begin{array}{c}\text { Timbunan } \\
\text { Sampah } \\
\left(\mathbf{m}^{\mathbf{3}} / \mathbf{h a r i}\right)\end{array}$} \\
\hline \multirow{3}{*}{ Kedungkandang } & RW 1 & 2,78 \\
\cline { 2 - 3 } & RW 2 & 4,03 \\
\cline { 2 - 3 } & RW 3 & 4,90 \\
\cline { 2 - 3 } & RW 6 & 3,13 \\
\hline total volume sampah yang masuk ke & $\mathbf{1 4 , 8 3}$ \\
TPS & \\
\hline
\end{tabular}

Berdasarkan tabel 5 dan 6 bahwa produksi sampah baru yang masuk ke TPS Kedungkandang 1 sebesar $35,27\left(\mathrm{~m}^{3} /\right.$ hari). Total produksi sampah TPS Kelurahan Kedungkandang sebesar $50,1 \mathrm{~m}^{3} /$ hari. TPS tersebut memiliki 2 kontainer untuk melayani 2 Kelurahan Kota Lama dan Kelurahan Kedungkandang

b. Penambahan Bangunan TPS Baru di Kelurahan Kedungkandang

Tabel 8. Produksi sampah yang akan masuk ke TPS baru Kelurahan Kedungkandang

\begin{tabular}{llr}
\hline \multirow{2}{*}{ Kelurahan } & \multicolumn{1}{c}{$\begin{array}{c}\text { Daerah } \\
\text { Pelayanan }\end{array}$} & $\begin{array}{c}\text { Produksi } \\
\text { sampah } \\
\text { (m³/hari) }\end{array}$ \\
\hline \multirow{3}{*}{ Buring } & RW 3 & 4,40 \\
\cline { 2 - 3 } & RW 4 & 3,00 \\
\cline { 2 - 3 } & RW 5 & 3,23 \\
\hline \multirow{2}{*}{ Kedungkandang } & RW 4 & 4,42 \\
\cline { 2 - 3 } & RW 5 & 3,69 \\
\hline \multicolumn{2}{l}{ Total sampah yang dihasilkan } & $\mathbf{1 8 , 7 2}$ \\
\hline
\end{tabular}

Produksi sampah yang masuk di TPS Kedungkandang 2 sebesar $18,72 \mathrm{~m}^{3} /$ hari. TPS 2 Kelurahan Kedungkandang memiliki 1 kontainer untuk melayani produksi sampah dari Kelurahan Kedungkandang (RW 4, RW 5) dan Kelurahan Buring (RW 3, RW 4, RW 5). 
2. $\quad$ TPS Buring

a. Penambahan kapasitas TPS Buring

Timbunan sampaha yang masuk di TPS Buring dapat dilihat pada Tabel 9.

Tabel 9. Timbunan Sampah yang Masuk di TPS Buring

\begin{tabular}{|c|c|c|}
\hline Kelurahan & Daerah Pelayanan & $\begin{array}{c}\text { Timbunan } \\
\text { Sampah } \\
\left(\mathbf{m}^{3} / \mathrm{hari}\right)\end{array}$ \\
\hline \multirow{3}{*}{ Bumiayu } & RW 1 & 5,95 \\
\hline & RW 2 & 9,66 \\
\hline & RW 3 & 8,52 \\
\hline \multirow{3}{*}{ Buring } & RW 1 & 4,52 \\
\hline & RW 2 & 2,72 \\
\hline & SMPN 10 Malang & 0,23 \\
\hline \multirow{2}{*}{ Wonokoyo } & RW 1 & 1,52 \\
\hline & RW 2 & 4,52 \\
\hline total volume sa & ah yang masuk ke TPS & 37,03 \\
\hline
\end{tabular}

Berdasarkan Tabel 9 terlihat bahwa timbunan sampah yang masuk ke TPS Buring sebanyak $37,03 \mathrm{~m}^{3} /$ hari. Timbunan sampah berasal dari 3 kelurahan yaitu Kelurahan Buring, Kelurahan Bumiayu dan Kelurahan Buring.

b. Penambahan TPS baru di Kelurahan Bumiayu

Berikut adalah produksi sampah yang akan masuk ke TPS Bumiayu dapat dilihat pada Tabel 10.

Tabel 10. Produksi sampah yang akan Masuk ke TPS Bumiayu

\begin{tabular}{llr}
\hline \multirow{2}{*}{ Kelurahan } & \multicolumn{1}{c}{$\begin{array}{c}\text { Daerah } \\
\text { Pelayanan }\end{array}$} & $\begin{array}{c}\text { Produksi } \\
\text { sampah } \\
\left(\mathbf{m}^{3} / \mathbf{h a r i}\right)\end{array}$ \\
\hline \multirow{3}{*}{ Bumiayu } & RW 4 & 5,61 \\
\cline { 2 - 3 } & RW 5 & 6,21 \\
\cline { 2 - 3 } & RW 6 & 3,88 \\
\hline $\begin{array}{l}\text { total volume } \\
\text { ke TPS }\end{array}$ & sampah yang masuk & $\mathbf{1 5 , 7 0}$ \\
\hline
\end{tabular}

Berdasarkan tabel 9. bahwa produksi sampah yang masuk ke TPS Bumiayu sebesar 15,70 $\left(\mathrm{m}^{3} /\right.$ hari $)$. Produksi sampah yang akan masuk ke TPS Bumiayu berasal dari RW 4, RW 5, dan RW 6 Kelurahan Bumiayu.

c. Penambahan TPS baru di Kelurahan Wonokoyo

Berikut dalah produksi sampah yang akan masuk ke TPS baru Kelurahan Wonokoyo Dapat dilihat pada Tabel 11.

Tabel 11. Produksi sampah yang akan Masuk ke TPS Wonokoyo

\begin{tabular}{llr}
\hline Kelurahan & \multicolumn{1}{c}{$\begin{array}{c}\text { Daerah } \\
\text { Pelayanan }\end{array}$} & $\begin{array}{c}\text { Produksi } \\
\text { sampah } \\
\left(\mathbf{m}^{3} / \mathbf{h a r i}\right)\end{array}$ \\
\hline \multirow{3}{*}{ Wonokoyo } & $\mathrm{RW} \mathrm{3}$ & 4,08 \\
\cline { 2 - 3 } & $\mathrm{RW} \mathrm{4}$ & 3,91 \\
\cline { 2 - 3 } & $\mathrm{RW} \mathrm{5}$ & 0,69 \\
\hline total volume sampah yang masuk ke & $\mathbf{8 , 6 8}$ \\
TPS & \\
\hline
\end{tabular}

Timbulan yang akan masuk ke TPS Wonokoyo sebesar 8,68 $\mathrm{m}^{3} /$ hari. Produksi sampah yang akan masuk ke TPS Wonokoyo berasal dari RW 3, RW 4, RW 5 Kelurahan Wonokoyo.

3. TPS Lesanpuro

a. Penambahan Kapasitas TPS Lesanpuro Untuk menghitung kebutuhan kapasitas TPS harus mengetahui jumlah volume sampah yang masuk ke TPS Lesanpuro. Berikut adalah produksi sampah yang masuk ke TPS Lesanpuro dapat dilihat pada Tabel 12.

Tabel 12. Timbunan Sampah di Daerah Pelayanan TPS Lesanpuro

\begin{tabular}{llr}
\hline \multirow{2}{*}{ Kelurahan } & \multicolumn{1}{c}{ Daerah Pelayanan } & \multicolumn{1}{c}{$\begin{array}{c}\text { Timbunan } \\
\text { Sampah }\left(\mathbf{m}^{\mathbf{3}} \mathbf{h a r i}\right)\end{array}$} \\
\hline & RW 1 & 7,15 \\
\cline { 2 - 3 } & RW 2 & 2,79 \\
\cline { 2 - 3 } Lesanpuro & RW 3 & 4,67 \\
\cline { 2 - 3 } & RW 4 & 2,73 \\
\cline { 2 - 3 } & RW 7 & 3,37 \\
\cline { 2 - 3 } & RW 8 & 3,34 \\
\cline { 2 - 3 } & RW 10 & 5,24 \\
\cline { 2 - 3 } & RW 11 & 4,51 \\
\cline { 2 - 3 } & Pasar lesanpuro & 0,318 \\
\hline total volume & sampah & $\mathbf{3 4 , 2}$ \\
\hline
\end{tabular}

Tabel 13. Timbunan Sampah di Daerah Pelayanan TPS Lesanpuro

\begin{tabular}{|c|c|c|}
\hline Kelurahan & Daerah Pelayanan & $\begin{array}{c}\text { Timbunan } \\
\text { Sampah } \\
\left(\mathbf{m}^{3} / \mathrm{hari}\right)\end{array}$ \\
\hline \multirow{9}{*}{ Lesanpuro } & RW 1 & 7,15 \\
\hline & RW 2 & 2,79 \\
\hline & RW 3 & 4,67 \\
\hline & RW 4 & 2,73 \\
\hline & RW 7 & 3,37 \\
\hline & RW 8 & 3,34 \\
\hline & RW 10 & 5,24 \\
\hline & RW 11 & 4,51 \\
\hline & Pasar lesanpuro & 0,318 \\
\hline \multicolumn{2}{|c|}{ total volume sampah yang masuk ke TPS } & 34,2 \\
\hline
\end{tabular}

Berdasarkan Tabel 13 timbunan sampah yang masuk ke dalam TPS Lesanpuro sebesar $34,2 \mathrm{~m}^{3} /$ hari. Kapasitas TPS yang dibutuhkan untuk mengelola sampah tersebut sebebesar $40 \mathrm{~m}^{3}$. Penambahan kapasitas pada TPS Lesanpuro yaitu dengan penambahan 1 kontainer Sehingga total kapasitas TPS Lesanpuro sebanyak 2 kontainer dengan total 5 kali ritasi.

b. Rencana TPS baru di daerah pelayanan TPS Lesanpuro

Tabel 14. Produksi sampah TPS Lesanpuro

\begin{tabular}{llr}
\hline \multirow{2}{*}{ Kelurahan } & Daerah Pelayanan & $\begin{array}{c}\text { Produksi sampah } \\
\left(\mathbf{m}^{\mathbf{3}} / \mathbf{h a r i}\right)\end{array}$ \\
\hline \multirow{3}{*}{ Lesanpuro } & $\mathrm{RW} 6$ & 2,3 \\
\cline { 2 - 3 } & $\mathrm{RW} 9$ & 2,7 \\
\cline { 2 - 3 } & $\mathrm{RW} 5$ & 4,3 \\
\hline total volume sampah ke TPS & $\mathbf{9 , 3}$ \\
\hline
\end{tabular}

Berdasarkan tabel 14 produksi sampah yang akan masuk kedalam TPS baru 
Kelurahan Lesanpuro sebesar 9,3 $\mathrm{m}^{3} /$ hari. Produksi sampah yang akan masuk kedalam TPS Lesanpuro berasal dari RW 5, RW 6, dan RW 9 Kelurahan Lesanpuro.

4. TPS Arjowinangun

a. Penambahan Kapasitas TPS Arjowinangun

Tabel 15. Jumlah Timbunan Sampah di Daerah Pelayanan TPS Arjowinangun

\begin{tabular}{llr}
\hline \multirow{2}{*}{ Kelurahan } & Daerah Pelayanan & \multicolumn{2}{c}{$\begin{array}{c}\text { Timbunan } \\
\text { Sampah } \\
\left(\mathbf{m}^{\mathbf{3}} / \mathbf{h a r i}\right)\end{array}$} \\
\hline \multirow{4}{*}{ Arjowinangun } & RW 1 & 2,30 \\
\cline { 2 - 3 } & RW 2 & 2,10 \\
\cline { 2 - 3 } & RW 5 & 3,63 \\
\cline { 2 - 3 } & RW 7 & 2,10 \\
\cline { 2 - 3 } & RW 9 & 5,14 \\
\hline \multirow{2}{*}{ Tlogowaru } & RW 1 & 0,57 \\
\cline { 2 - 3 } & RW 2 & 1,09 \\
\hline total volume sampah yang masuk ke & $\mathbf{1 6 , 9 2}$ \\
TPS & & \\
\hline
\end{tabular}

Tabel 16. Jumlah Produksi sampah yang akan Masuk ke TPS Arjowinagun

\begin{tabular}{llr}
\hline \multirow{2}{*}{ Kelurahan } & Daerah Pelayanan & \multicolumn{1}{c}{$\begin{array}{c}\text { Timbunan } \\
\text { Sampah }\left(\mathbf{m}^{\mathbf{3}} \mathbf{h a r i}\right)\end{array}$} \\
\hline \multirow{4}{*}{ Arjowinangun } & $\mathrm{RW} \mathrm{3}$ & 3,74 \\
\cline { 2 - 3 } & $\mathrm{RW} \mathrm{4}$ & 3,31 \\
\cline { 2 - 3 } & $\mathrm{RW} \mathrm{6}$ & 0,75 \\
\cline { 2 - 3 } & $\mathrm{RW} \mathrm{8}$ & 1,80 \\
\hline \multirow{2}{*}{$\begin{array}{l}\text { total volume } \\
\text { TPS }\end{array}$} & sampah yang masuk ke & $\mathbf{9 , 6 0}$ \\
\hline
\end{tabular}

Total produksi sampah yang akan masuk ke TPS Arjowinangun yaitu 26,52 $\left(\mathrm{m}^{3} /\right.$ hari).Produksi sampah yang akan masuk ke TPS Arjowinangun berasal dari RW 3, RW 4, RW 6, RW 8 Kelurahan Arjowinangun. Total kapasitas TPS yang disediakan sebesar $32 \mathrm{~m}^{3}$. Alat pengumpul sampah yang dibutuhkan untuk mengumpulkan sampah sebanyak 11 gerobak dengan ritasi 2-3 kali. Sedangkan ritasi pengangkutan sampah dari TPS ke TPA sebanyak 2 kali angkut tiap kontainer.

b. Penambahan TPS baru di daerah pelayanan TPS Arjowinangun

Berikut adalah produksi sampah yang masuk ke TPS baru Kelurahan Tlogowaru.

Tabel 17. Produksi sampah yang Masuk ke TPS Tlogowaru

\begin{tabular}{llr}
\hline Kelurahan & Daerah Pelayanan & $\begin{array}{c}\text { Produksi sampah } \\
\left(\mathbf{m}^{\mathbf{3}} \mathbf{h} \mathbf{h a r i}\right)\end{array}$ \\
\hline \multirow{4}{*}{ Tlogowaru } & RW 3 & 2,43 \\
\cline { 2 - 3 } & RW 4 & 1,93 \\
\cline { 2 - 3 } & RW 5 & 2,23 \\
\cline { 2 - 3 } & RW 6 & 1,80 \\
\cline { 2 - 3 } & RW 8 & 1,12 \\
\hline \multirow{2}{*}{ total volume sampah ke TPS } & $\mathbf{9 , 5 1}$ \\
\hline
\end{tabular}

Produksi sampah yang masuk kedalam TPS baru Kelurahan Tlogowaru sebesar 9,51 $\left(\mathrm{m}^{3} /\right.$ hari).. TPS tersebut melayani (RW 3, RW 4, RW 5, RW 6, RW 8) Kelurahan Tlogowaru yang belum terlayani oleh petugas pengumpul sampah. Alat pengumpulan sampah yang dibutuhkan sebanyak 5unit dengan kapasitas gerobak 1 $\mathrm{m}^{3}$ dan ritasi pengambilan maksimal 2 kali. Total kapasitas yang disediakan untuk TPS baru Kelurahan Tlogowaru sebesar $8 \mathrm{~m}^{3}$. Ritasi pengangkutan dilakukan sebanyak 1 kali angkut dari TPS ke TPA.

5. TPS Danau Bratan

Rencana pada TPS Danau Bratan yaitu menambahkan kapasitasTPS dengan menambahkan ritasi pada pengangkutan sampah dari TPS menuju TPA. Berdasarkan eksisting ritasi pengangkutan sebanyak 2 kali angkut. Kapasitas TPS tersebut belum mampu menampung seluruh sampah yang dikumpulkan dari penduduk sebesar 22,90 $\mathrm{m}^{3}$, Selain itu, seluruh penduduk sudah terlayani oleh TPS dan radius pelayanannya masih terjangkau dalam $1000 \mathrm{~m}$ sehingga perlu penambahan ritasi pengangkutan sebanyak 1 kali. Rencana kinerja TPS Danau Bratan total kapasitas yang disediakan menjadi $24 \mathrm{~m}^{3}$.

6. TPS Cemorokandang

a. Penambahan kapasitas TPS Cemorokandang

Tabel 18. Timbunan Sampah di Daerah Pelayanan TPS Cemorokandang

\begin{tabular}{clr}
\hline \multirow{2}{*}{ Kelurahan } & \multicolumn{1}{c}{$\begin{array}{c}\text { Daerah } \\
\text { Pelayanan }\end{array}$} & $\begin{array}{c}\text { Timbunan Sampah } \\
\left(\mathbf{m}^{\mathbf{3}} / \mathbf{h a r i}\right)\end{array}$ \\
\hline \multirow{4}{*}{ Cemorokandang } & RW 1 & 2,08 \\
\cline { 2 - 3 } & RW2 & 2,81 \\
\cline { 2 - 3 } & RW 5 & 1,08 \\
\cline { 2 - 3 } & RW 7 & 2,17 \\
\cline { 2 - 3 } & RW 8 & 2,10 \\
\cline { 2 - 3 } & RW 9 & 2,36 \\
\hline total volume sampah ke TPS & $\mathbf{1 2 , 6 1}$ \\
\hline
\end{tabular}

Rencana penambahan kapasitas pada TPS Cemorokandang dengan penambahan ritasi pada pengangkutan sampah sebanyak 1 kali sehingga total kapasitas TPS Cemorokandang sebesar $16 \mathrm{~m}^{3}$.

b. Pembangunan TPS baru di Kelurahan Cemorokandang

Tabel 19. Produksi sampah yang Masuk ke TPS Cemorokandang

\begin{tabular}{llr}
\hline \multirow{2}{*}{ Kelurahan } & \multicolumn{1}{c}{$\begin{array}{c}\text { Daerah } \\
\text { Pelayanan }\end{array}$} & $\begin{array}{c}\text { Produksi sampah } \\
\left(\mathbf{m}^{\mathbf{3}} / \mathbf{h a r i}\right)\end{array}$ \\
\hline \multirow{4}{*}{ Cemorokandang } & 2,08 \\
\cline { 2 - 3 } & $\mathrm{RW} \mathrm{1}$ & 3,29 \\
\cline { 2 - 3 } & $\mathrm{RW} \mathrm{3}$ & 4,67 \\
\cline { 2 - 3 } & $\mathrm{RW} \mathrm{4}$ & 2,20 \\
\cline { 2 - 3 } & $\mathrm{RW} \mathrm{5}$ & 2,43 \\
\cline { 2 - 3 } & $\mathrm{RW} \mathrm{10}$ & 1,89 \\
\hline total volume sampah yang masuk ke & $\mathbf{1 6 , 5 7}$ \\
TPS & & \\
\hline
\end{tabular}

Berdasarkan Tabel 19 produksi sampah yang akan masuk kedalam TPS baru Kelurahan Cemorokandang sebesar $16,57 \mathrm{~m}^{3} /$ hari. Produksi sampah yang akan masuk kedalam TPS Cemorokandang 2 berasal dari RW 1, RW 3, RW 
4, RW 5, RW 10, dan RW 11 Kelurahan Cemorokandang.

Tabel 20. Kesimpulan Rekomendasi TPS di Kecamatan Kedungkandang

\begin{tabular}{|c|c|}
\hline TPS & Alternatif Solusi \\
\hline Kedungkandang & $\begin{array}{l}\text { Penambahan TPS baru dan penambahan } \\
\text { kapasitas di Kelurahan Kedungkandang } \\
\text { untuk daerah yang tidak terlayani petugas } \\
\text { pengumpul sampah dan produksi sampah } \\
\text { dari Kelurahan Kota Lama }\end{array}$ \\
\hline Arjowinangun & $\begin{array}{l}\text { Penambahan TPS pada Kelurahan } \\
\text { Tlogowaru dan penambahan kapasitas pada } \\
\text { TPS arjowinangun untuk melayani daerah di } \\
\text { arjowinangun yang belum terlayani oleh } \\
\text { TPS. }\end{array}$ \\
\hline Buring & $\begin{array}{l}\text { Penambahan kapasitas TPS dan } \\
\text { penambahan TPS baru pada Kelurahan } \\
\text { Bumiayu dan Kelurahan Wonokoyo untuk } \\
\text { mengurangi beban TPS Buring dan untuk } \\
\text { melayani daerah-daerah yang belum } \\
\text { terlayani oleh petugas pengumpul sampah. } \\
\text { Selain itu, rekomendasi untuk membangun } \\
\text { TPS Buring agar memiliki prasarana yang } \\
\text { lengkap }\end{array}$ \\
\hline Danau Bratan & $\begin{array}{l}\text { Penambahan kapasitas } \text { TPS r untuk } \\
\text { mengangkut sampah yang masih tertinggal } \\
\text { di TPS Bratan }\end{array}$ \\
\hline Lesanpuro & $\begin{array}{l}\text { Penambahan TPS baru dan penambahan } \\
\text { kapasitas TPS untuk daerah yang belum } \\
\text { terlayani oleh petugas pengumpul sampah } \\
\text { dan penambahan kapasitas pada TPS } \\
\text { eksisting }\end{array}$ \\
\hline Cemorokandang & $\begin{array}{l}\text { Penambahan TPS baru dikarenakan TPS } \\
\text { eksisting dibangun untuk melayani } \\
\text { masyarakat yang tinggal di Perumahan } \\
\text { Satelit Buring dan penambahan kapasitas } \\
\text { TPS }\end{array}$ \\
\hline $\begin{array}{l}\text { Bayangan Kota } \\
\text { Lama }\end{array}$ & $\begin{array}{l}\text { Untuk daerah yang belum terlayani oleh } \\
\text { petugas pengumpul sampah diarahkan untuk } \\
\text { membuang sampah ke TPS Kedungkandang }\end{array}$ \\
\hline
\end{tabular}

\section{Analisis Overlay}

Tahapan dalam analisis overlay yaitu dengan menyeleksi lahan kosong dengan kriteria kelerengan, sempadan sungai, jaringan jalan, jarak dengan permukiman, radius pelayanan. Hasil dari analisis beberapa kriteria tersebut menghasilkan lahan kosong yang dapat dijadikan untuk pembangunan TPS baru di Kecamatan Kedungkandang yang dapat dilihat pada Gambar 5 .

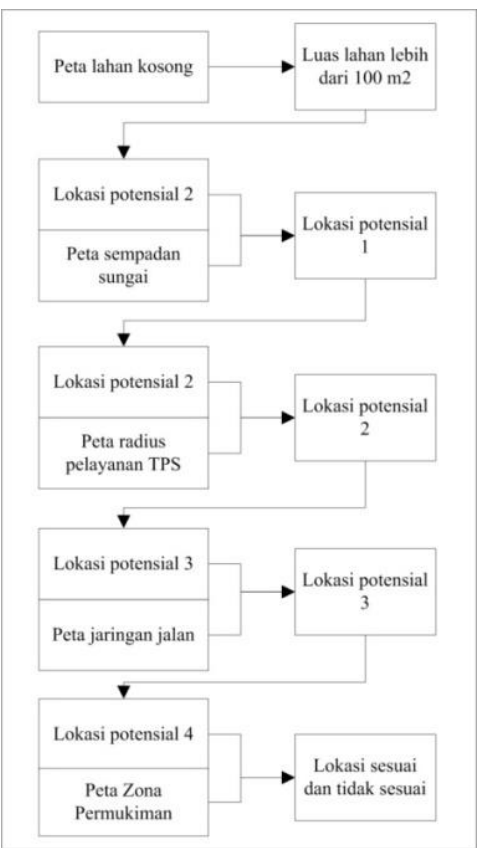

Gambar 5. Alur Analisis Overlay

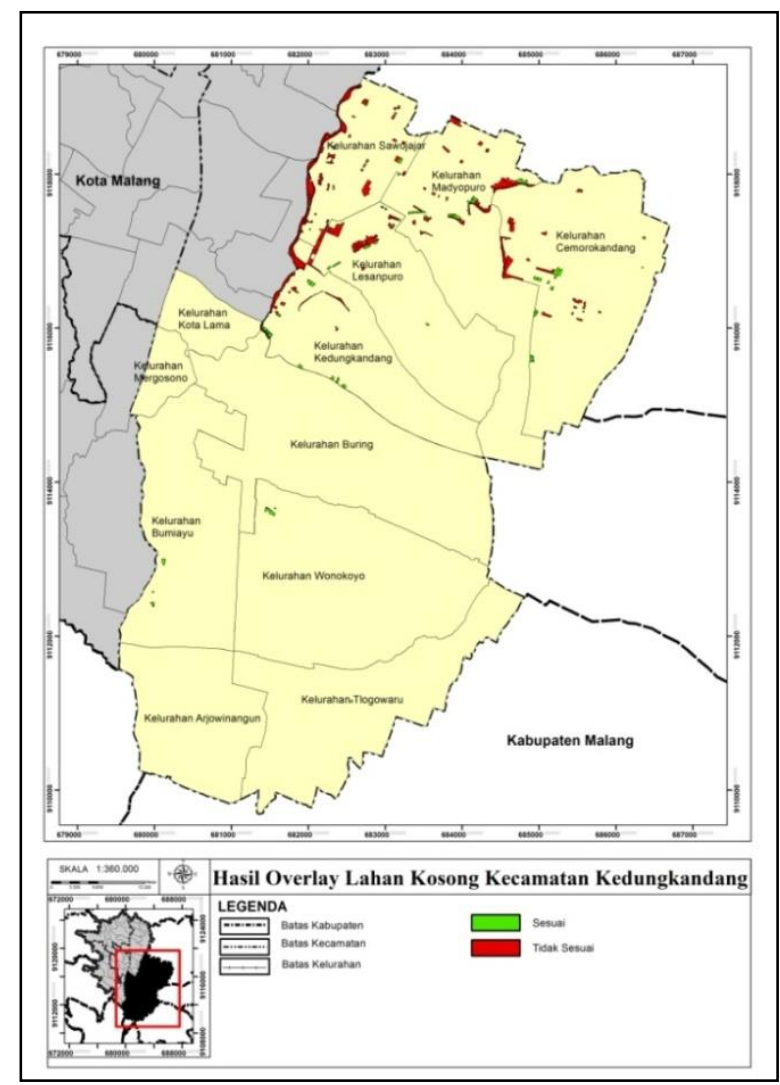

Gambar 6. Hasil Overlay Lahan Kosong

Berdasarkan Gambar 6 diketahui bahwa lahan yang sesuai untuk penentuan lokasi TPS yaitu berwarna hijau sedangkan lahan yang berwarna merah tidak dapat digunakan sebagai lokasi 


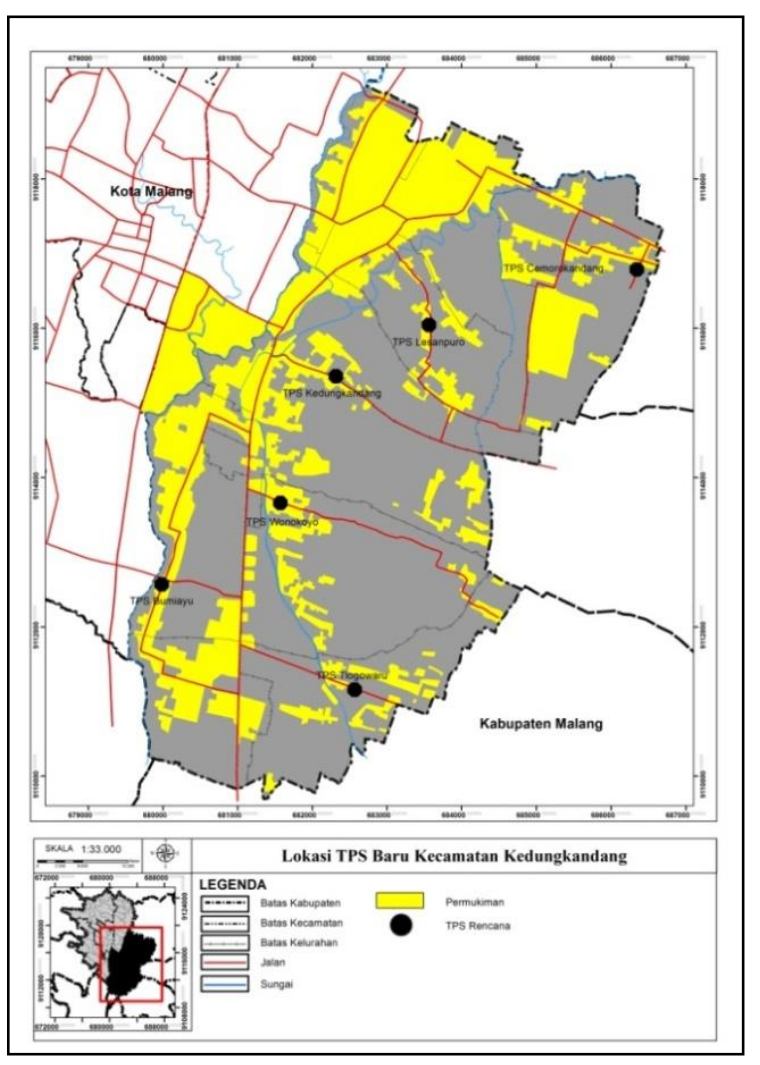

Gambar 7. Lokasi TPS di Kecamatan Kedungkandang

\section{Penentuan Rute TPS Baru dan operasional Pengangkutan}

1. TPS Cemorokandang 2

Rencana lokasi TPS Kelurahan

Cemorokandang 2 berada di RW 10. Alat pengumpulan yang dibutuhkan di TPS tersebut sebanyak 8 unit dengan ritasi maksimal 3 kali. Kendaran yang digunakan untuk pengangkutan sampah ke TPA berjenis Armroll Truk.Rutepengangkutan TPS Cemorokandang 2 melewati Jalan Raya Cemorokandang - Jalan Madyopuro - Jalan Ki Ageng Gribig - Jalan Mayjend Sungkono - Jalan Muharto - Jalan Zainal Zakse - Jalan Kyai Tamrin - Jalan Syarif Al Qodri - Jalan Ade Irma Suryani - Jalan I.R Rais - Jalan Raya Bandulan - Jalan Tebo - Jalan Rawisari - TPA Supit Urang dengan ritasi pengangkutan sampah 2 kali. Jadwal pengambilan sampah di TPS pukul 08.00 membutuhkan waktu 1 jam 10 menit dan pukul 10.00 membutuhkan waktu 2 jam 10 menit.

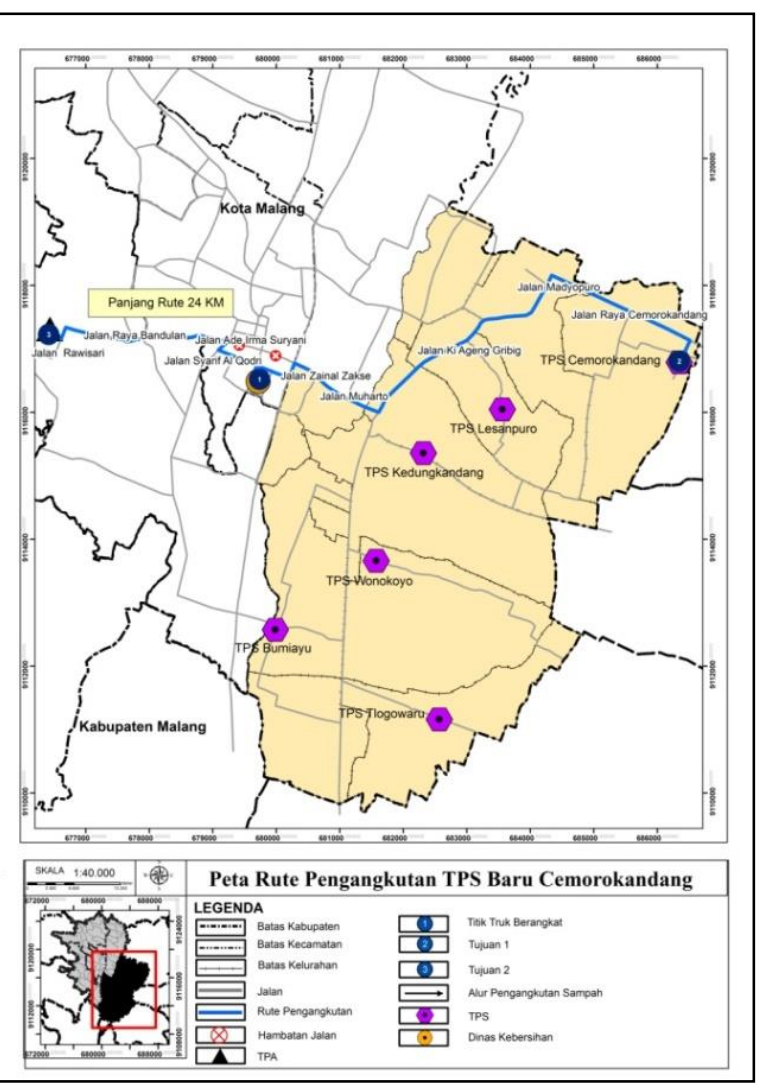

Gambar 8. Rute Pengangkutan TPS Baru Cemorokandang

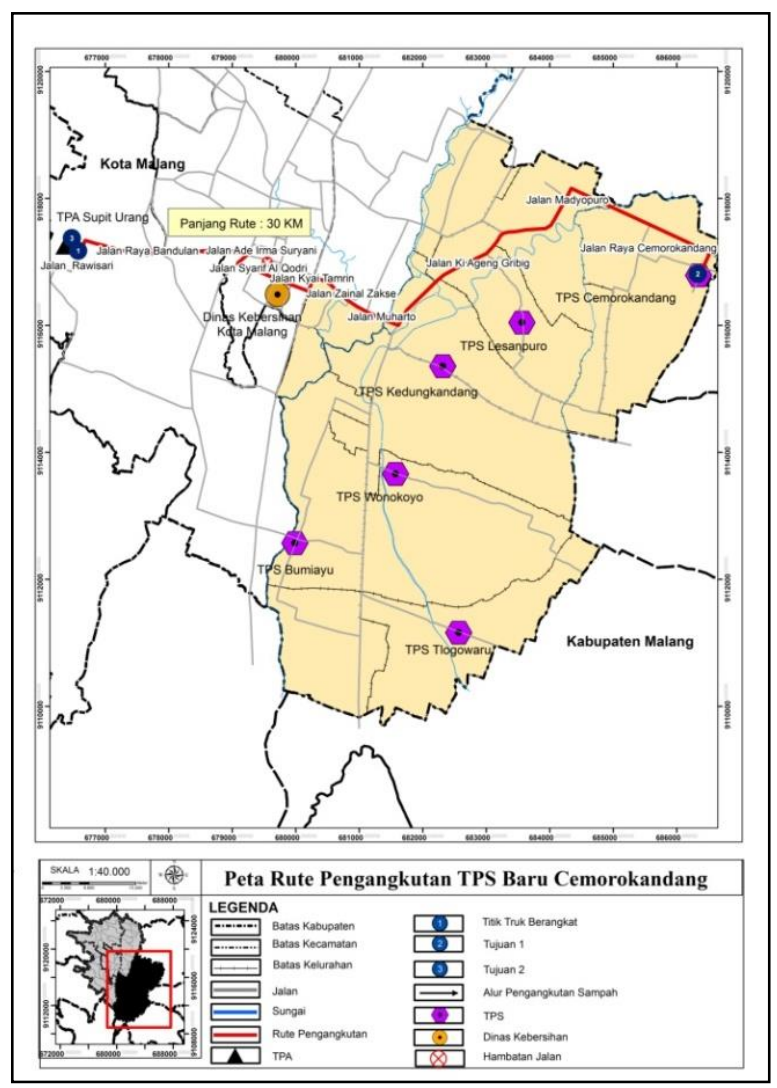

Gambar 9. Rute Pengangkutan TPS Baru Cemorokandang

2. Kelurahan Tlogowaru

Lokasi TPS Kelurahan Tlogowaru berada di lahan kosong RW 4. Alat pengumpul sampah yang dibutuhkan untuk mengumpulkan sampah 
sebanyak 5 unit yang disebar ditiap-tiap RW. Jenis kendaraan yang digunakan untuk mengangkut sampah menggunkan Armroll Truk. Rute yang dilewati oleh truk pengangkut yaitu Jalan Raya Tlogowaru - Jalan Mayjen Sungkono - Jalan Gadang Bumiayu- Jalan Aipda Satsui Tubun - Jalan Supriadi - Jalan Mergan -Jalan Tebo - Jalan Rawisari - TPA Supit Urang dengan ritasi sebanyak 1 kali dengan jadwal pengangkutan pukul 10.00 dan waktu tempuh yang dibutuhan dari TPA ke TPS ke TPA 1 jam 20 menit.

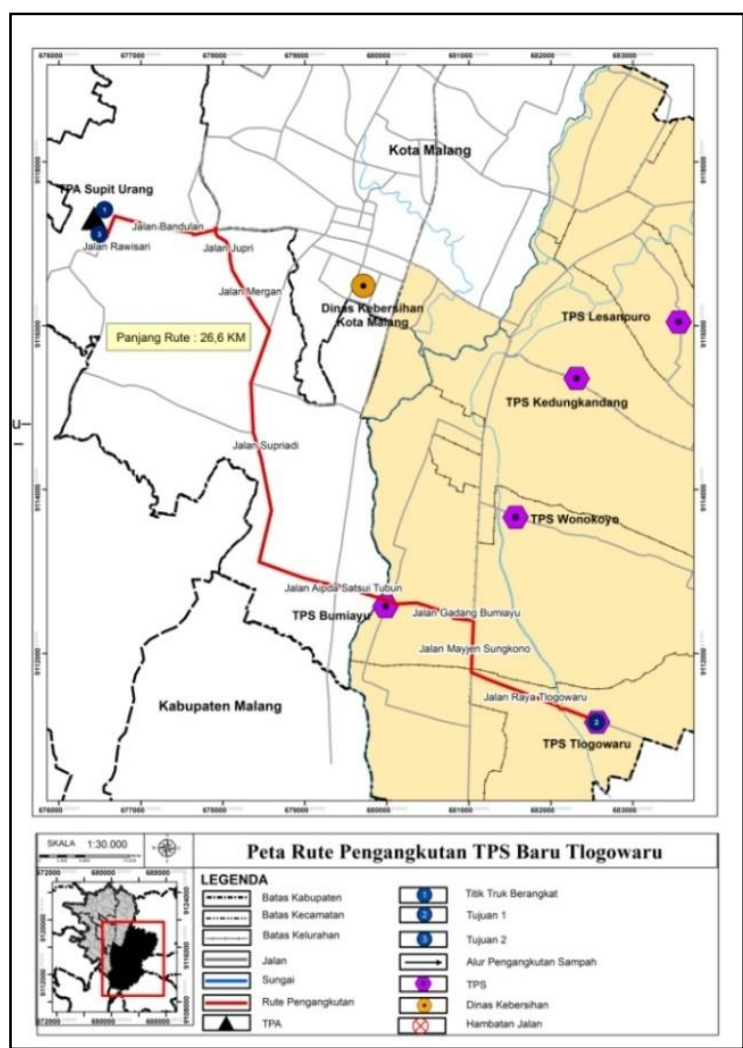

Gambar 10. Rute Pengangkutan TPS Baru Tlogowaru

3. TPS Cemorokandang 2

Rencana lokasi TPS Kelurahan Cemorokandang 2 berada di RW 10 . Alat pengumpulan yang dibutuhkan di TPS tersebut sebanyak 8 unit dengan ritasi maksimal 3 kali. Kendaran yang digunakan untuk pengangkutan sampah ke TPA berjenis Armroll Truk.Rutepengangkutan TPS Cemorokandang 2 melewati Jalan Raya Cemorokandang - Jalan Madyopuro - Jalan Ki Ageng Gribig - Jalan Mayjend Sungkono - Jalan Muharto - Jalan Zainal Zakse - Jalan Kyai Tamrin - Jalan Syarif Al Qodri - Jalan Ade Irma Suryani - Jalan I.R Rais - Jalan Raya Bandulan - Jalan Tebo - Jalan Rawisari - TPA Supit Urang dengan ritasi pengangkutan sampah 2 kali. Jadwal pengambilan sampah di TPS pukul 08.00 membutuhkan waktu 1 jam 10 menit dan pukul 10.00 membutuhkan waktu 2 jam 10 menit.

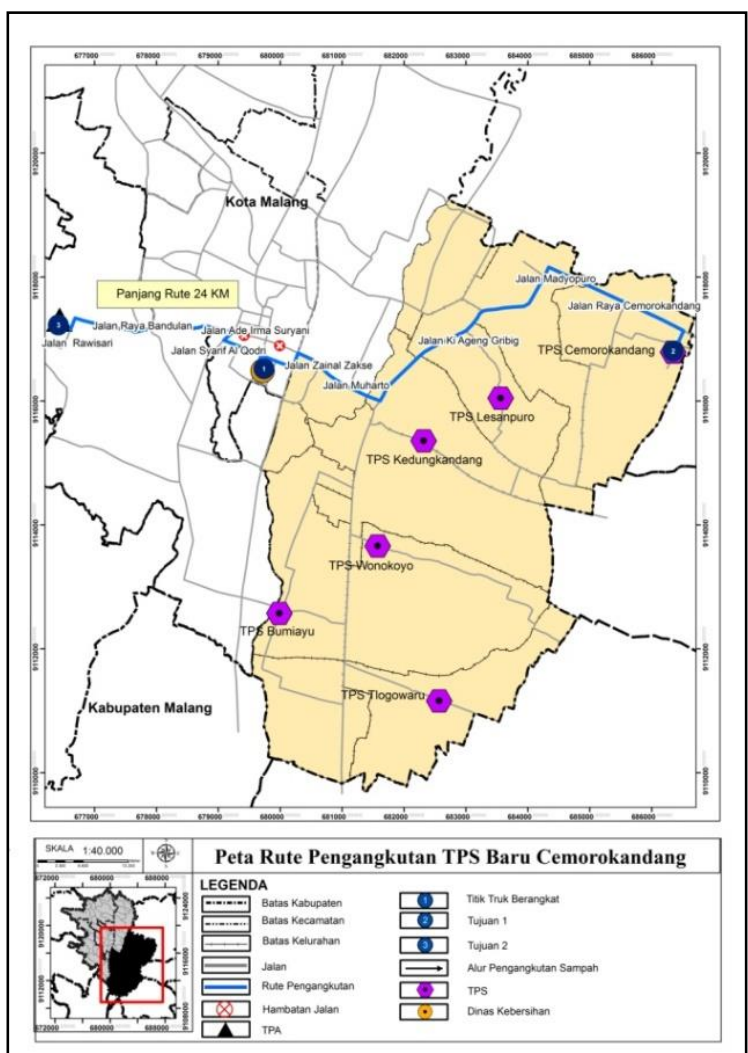

Gambar 11. Rute Pengangkutan TPS Baru Cemorokandang

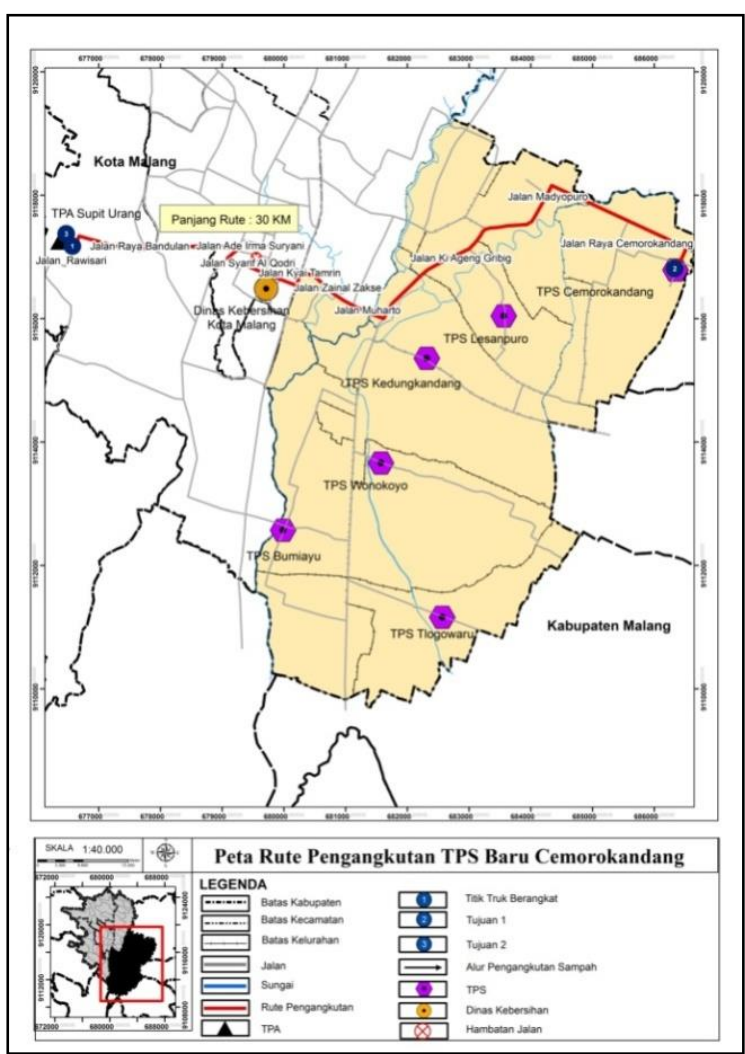

Gambar 12. Rute Pengangkutan TPS Baru Cemorokandang 


\section{TPS Kedungkandang 2}

Rencana lokasi

Kedungkandang berada di RW 3. Ala pengumpulan yang dibutuhkan untuk mengumpulkan sampah dari rumah tangga sebanyak 5 unit gerobak yang disebar ditiap-tiap RW yang dilayani dan ritasi maksimal 3 kali. Kendaraan yang digunakan untuk mengangkut sampah menuju TPS jenis Armroll Truk. Rute pengangkutan sampah melalui Jalan Raya Puncak Buring Indah - Jalan Mayjend Sungkono - Jalan Muharto - Jalan Zainal Zakse - Jalan Kyai Tamrin - Jalan Syarif Al Qodri - Jalan Ade Irma Suryani - Jalan I.R Rais - Jalan Raya Bandulan Jalan Tebo - Jalan Rawisari - TPA Supit Urang dengan ritasi sebanyak 2 kali pengangkutan. Jadwal pengangkutan ketika pukul 10.00 dan 12.00 dan membutuhkan waktu 1 jam 30 menit.

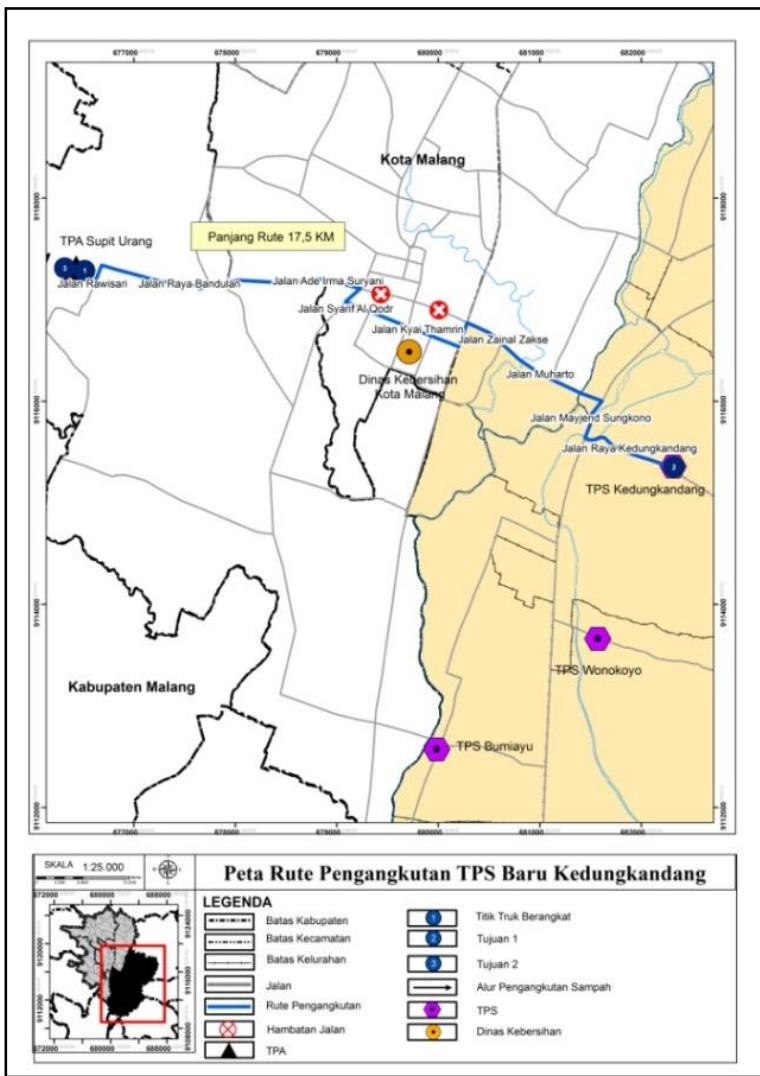

Gambar 13. Rute Pengangkutan TPS Baru Kedungkandang

5. TPS Lesanpuro 2

Rencana lokasi TPS Kelurahan Lesanpuro 2 berada di RW 5. Alat pengumpulan yang dibutuhkan sebanyak 6 unit gerobak dengan ritasi maksimal 3 kali. Kendaran yang digunakan untuk pengangkutan sampah ke TPA berjenis Armroll Truk. Rute pengangkutan sampah dari TPS TPA Supit Urang melewati Jalan Raya Lesanpuro - Jalan Ki Ageng Gribig - Jalan Mayjend Sungkono - Jalan Muharto - Jalan Zainal Zakse - Jalan Kyai Tamrin - Jalan Syarif
Al Qodri - Jalan Ade Irma Suryani - Jalan I.R Rais - Jalan Raya Bandulan - Jalan Tebo - Jalan Rawisari - TPA Supit Urang dengan ritasi 1 kali pengangkutan. Jadwal pengangkutan pukul 08.00 dan waktu tempuh yang dibutuhkan selama 55 menit.

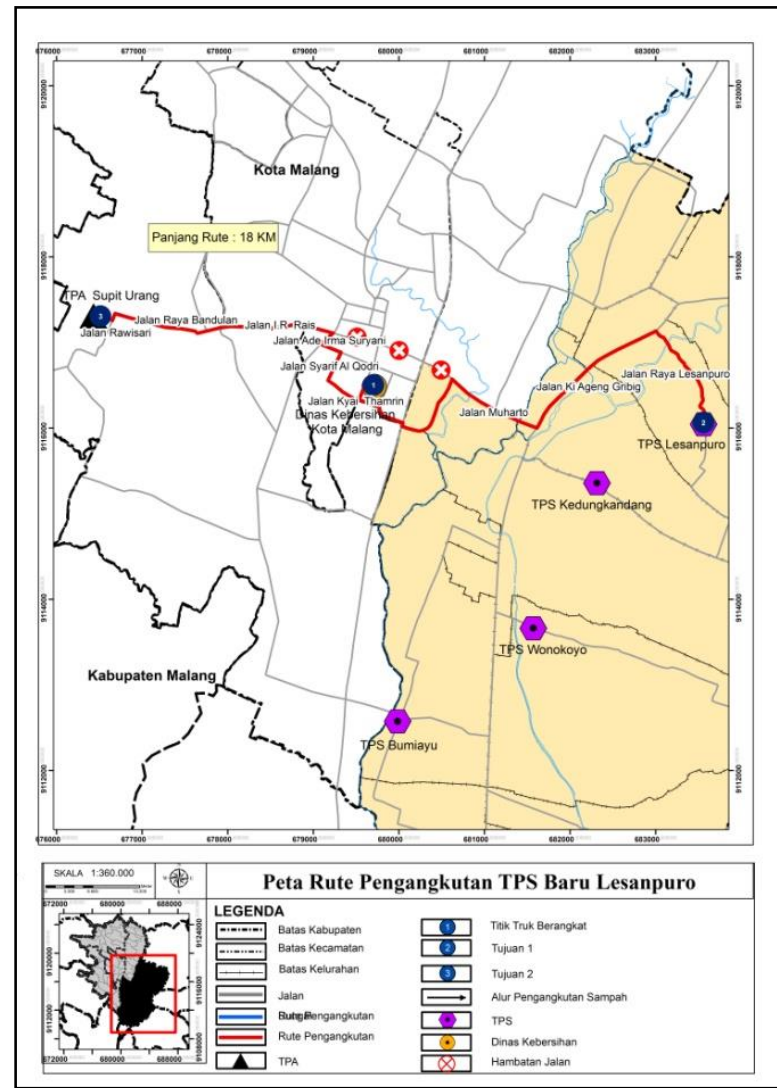

Gambar 14. Rute Pengangkutan TPS Baru Lesanpuro

6. TPS Kelurahaan Bumiayu

Rencana lokasi TPS Kelurahan Bumiayu berada di RW 5. Alat pengumpul sampah yang dibutuhkan sebanyak 6 unit dengan ritasi maksimal 3 kali pengambilan. Kendaran yang digunakan untuk pengangkutan sampah ke TPA berjenis Armroll Truk. Rute pengangkutan sampah TPS Bumiayu melewati Jalan Gadang Bumiayu - Jalan Aipda Satsui Tubun - Jalan Supriadi - Jalan Mergan - Jalan Jupri - Jalan Bandulan - Jalan Tebo - Jalan Rawisari - TPA Supit Urang. Ritasi di TPS Bumiayu sebanyak 2 kali pengangkutan. Dengan jadwal pengangkutan pukul 08.00 membutuhkan waktu 50 menit dan pukul 12.00 membutuhkan waktu 1 jam. 


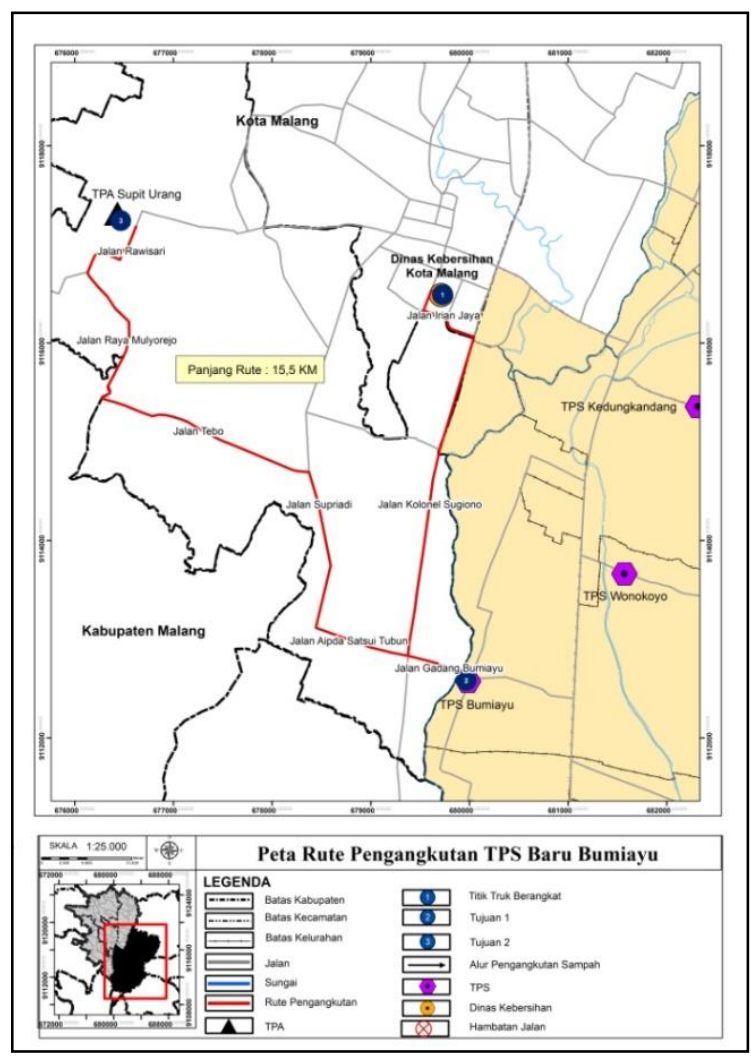

Gambar 15. Rute pengangkutan TPS Baru Bumiayu 1

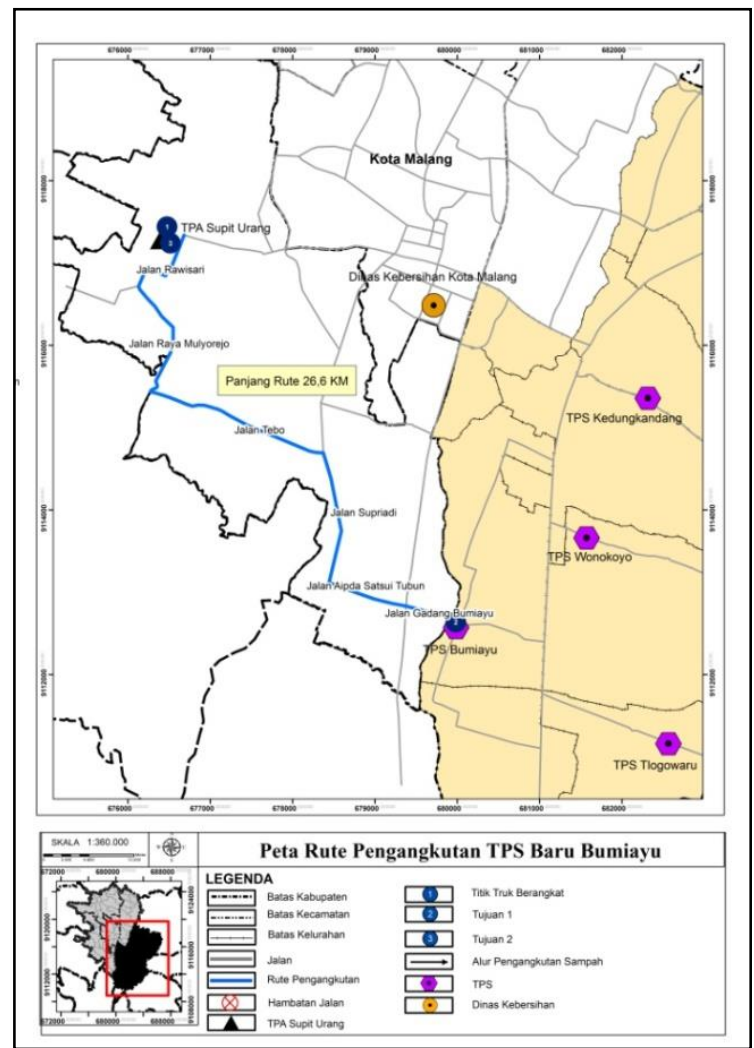

Gambar 16. Rute pengangkutan TPS Baru Bumiayu 2

7. TPS Kelurahan Wonokoyo

Rencana lokasi TPS Kelurahan Wonokoyo berada di RW 4. Alat pengumpuan sampah yang dibutuhkan di TPS tersebut sebanyak 5 unit gerobak dengan ritasi maksimal 4 kali. Kendaran yang digunakan untuk pengangkutan sampah ke TPA berjenis Armroll Truk.Rute pengangkutan sampah TPS Wonokoyo melewati Jalan Raya Wonokoyo - Jalan Mayjend Sungkono - Jalan Muharto - Jalan Zainal Zakse - Jalan Kyai Tamrin - Jalan Syarif Al Qodri - Jalan Ade Irma Suryani - Jalan I.R Rais - Jalan Raya Bandulan Jalan Tebo - Jalan Rawisari - TPA Supit Urang dengan ritasi pengangkutan sebanyak 1 kali. Jadwal pengakutan sampah pukul 12.00 dan membutuhkan waktu selama 1 jam 40 menit

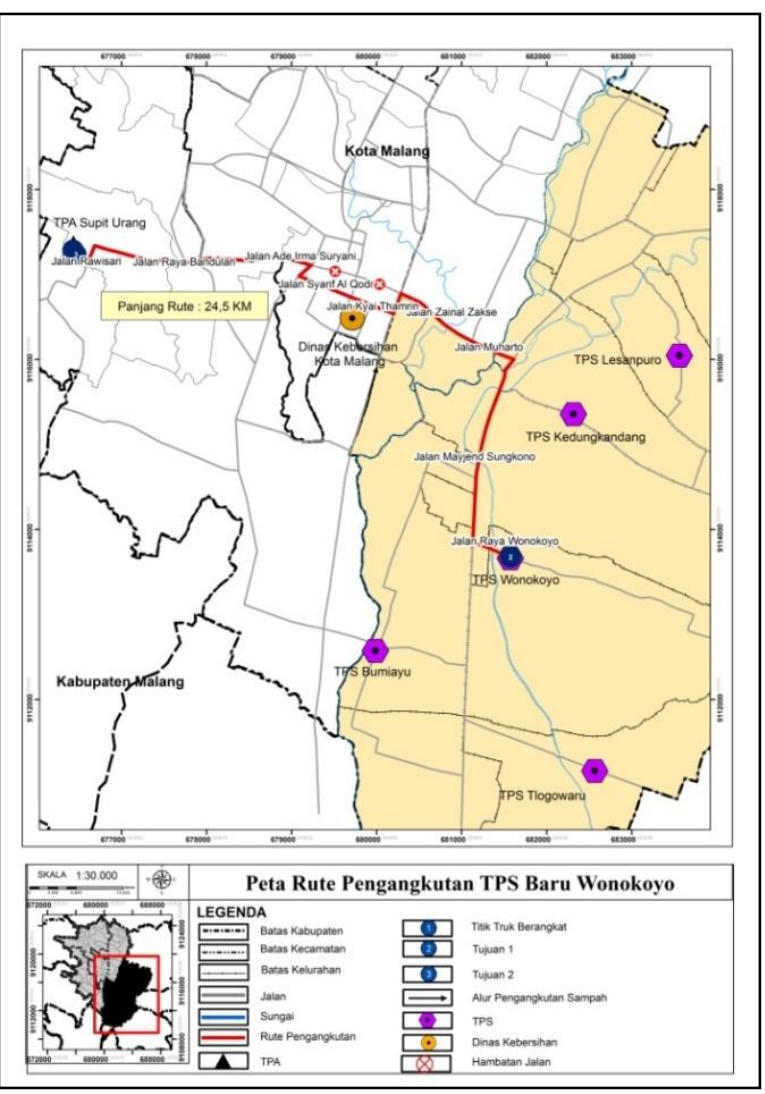

Gambar 17. Rute Pengangkutan TPS Baru Wonokoyo

\section{KESIMPULAN}

1. Sarana pemindahan sampah di Kecamatan Kedungkandang bahwa total produksi sampah yang dihasilkan oleh masyarakat Kecamatan Kedungkandang sebesar 412,3 $\mathrm{m}^{3} /$ hari sedangkan sarana pemindahan yang disediakan oleh pemerintah sebesar $210 \mathrm{~m}^{3}$. Rekomendasi yang dilakukan yaitu penambahan kapasitas sarana pemindahan di Kecamatan Kedungkandang.

a. Penambahan kapasitas sarana pemindahan dilakukan pada TPS Kedungkandang, TPS Kota Lama, TPS Arjowinangun, TPS Buring, TPS Lesanpuro, TPS Cemorokandang, TPS Bratan dikarenakan masih terdapat penduduk yang tidak terlayani oleh TPS. 
b. Untuk daerah yang tidak terlayani oleh TPS dan memiliki jarak jangkauan lebih dari 1000 meter dari TPS yang tersedia maka direkomendasikan untuk pembangunan TPS baru di Kelurahan Bumiayu, Kelurahan Tlogowaru, Kelurahan Kedungkandang, Kelurahan Wonokoyo, Kelurahan Lesanpuro, Kelurahan Cemorokandang.

2. Rekomendasi operasional sistem pengangkutan sampah pada TPS baru meliputi rute pengangkutan dan operasional pengangkutan.

a. Rekomendasi rute pengangkutan dipilih jarak terdekat dari TPS menuju TPS dengan mempertimbangkan hambatan jalan seperti jalan satu arah, pasar tumpah, jam pucak kepadatan kendaraan.

b. Rekomendasi operasional pengangkutan sampah meliputi penentuan jam operasional pengangkutan TPS-TPA, waktu yang dibutuhkan untuk mengangkut sampah dan ritasi yang dilakukan untuk mengangkut seluruh sampah di TPS. Penentuan jam operasional pengangkutan dimana maksimal berangkat dari TPS pukul 12.00 dikarenakan ada pembatasan jam operasional di TPS pukul $05.00-12.00$ sedangkan untuk pembatasan operasional TPA pukul 16.00. Ritasi yang dilakukan maksimal 3 kali pengangkutan.

\section{DAFTAR PUSTAKA}

Achmad, ismid.2015. Strategi Penentuan Lokasi dan Kebutuhan Lahan TPS Berdasarkan Fungsi Kawasan di Kota Denpasar. Universitas Udayana Bali. Volume 9 nomor 1 tahun 2015.

Badan Standarisasi Nasional. (2008). SNI - 3242 - 2008 Tentang Tata Cara Pengelolaan Sampah Permukiman. Jakarta: Badan Standarisasi Nasional.

Badan Standar Nasional. 2002. SNI 19 - 2454 2002 Tata Cara Teknik Operasional Pengelolaan Sampah Perkotaan. Badan Standarisasi Nasional. Jakarta

Badan Pusat Statistik Kota Malang. (2016). Kecamatan Kedungkandang Dalam Angka 2016. Malang: BPS Kota Malang.

Dinas Lingkungan Hidup. 2016. Rencana Induk Persampahan tahun 2016 Kota Malang. Malang:DLH

Faza, Aida Ulfa.dkk. 2015. Analisis Permodelan SIG Penentuan Lokasi TPS Kecamatan Banyumanik Semarang. Semarang: Universitas Diponegoro.
Menteri Pekerjaan Umum Republik Indonesia. (2013). Peraturan Menteri Pekerjaan Umum Republik Indonesia Nomor 03/PRT/M/2013 Tentang Penyelenggaraan Prasarana dan Sarana Persampahan Dalam Penanganan Sampah Rumah Tangga dan Sampah Sejenis Sampah Rumah Tangga. Jakarta: Kementrian Pekerjaan Umum.

Mulyansyah, Andri. 2008. Tempat pembuangan sampah sementara di Jakarta Timur. Skripsi. Jakarta : Universitas Indonesia.

Pemerintah Kota Malang. 2010. Peraturan Daerah Kota Malang Nomor 10 Tahun 2010 tentang Pengelolaan Sampah. Malang: Kota Malang

Pemerintah Kota Malang. 2014. Buku Putih Sanitasi Kota Malang Tahun 2014. Malang: Pemerintah Kota Malang

Pramono, Sigit. 2013. Studi Mengenai Komposisi Sampah Perkotaan di Negara-Negara Berkembang. Jakarta : Jurnal FTSP Universitas Gunadarma

Rizal, Mohammad. 2017. Analisis Pengelolaan Persampahan Perkotaan. Jurnal Smartek. Vol. 09 no 2 Mei 2017:155-172 
REKOMENDASI PENENTUAN TITIK TEMPAT PENAMPUNGAN SAMPAH SEMENTARA DI KECAMATAN KEDUNGKANDANG KOTA MALANG 